\title{
BUSINESS ORGANIZATIONAL RESPONSE TO ENVIRONMENTAL ISSUES
}

\author{
Mustafa Gursoy ${ }^{{ }^{*}}$ \\ 1*University of Mediterranean Karpasia, Department of Business Administration, North Cyprus; \\ *Corresponding Author Behcet Oznacar, e-mail: gursoycy@gmail.com;
}

Received November 2021; Accepted December 2021; Published January 2022;

DOI: https://doi.org/10.31407/ijees12.128

\begin{abstract}
Environmental issues comprise a vital driver of innovation in business companies. The article begins from the historical view by recognizing the factors and substantial steps in technological innovation associated with raising environmental awareness in recent history. Our research is carried out to determine the similarities and differences between the perceptions of e-business managers of Northern Cyprus and Turkey regarding creativity in environmental issues in the organization. To do so, a descriptive research model is utilized. The research provides information on the extent to which the problems experienced by comparing Northern Cyprus and Turkey are similar to one. It is understood that the new ideas of the creative, managers, and employees related to the business and environmental challenges can be put together, and from these ideas, productivity and production can come to a much better situation with the new management that the business will know to implement. Creativity is not only a thought structure that is necessary to increase the production and productivity of the work-life, to survive international competition, to succeed, but also essential for the growth of the adult youth of the countries as much higher quality people.
\end{abstract}

Keywords: environmental issues; Business organizational response; Managers; business companies. 